\title{
The role of worked-example in enhancing students' self-explanation and cognitive efficiency in calculus instruction
}

\author{
Cecep Anwar Hadi Firdos Santosa ${ }^{1}$ *, Didi Suryadi ${ }^{2}$, Sufyani Prabawanto ${ }^{2}$, S. Syamsuri ${ }^{1}$ \\ ${ }^{1}$ Mathematics Education Department, Universitas Sultan Ageng Tirtayasa. \\ Jalan Raya Jakarta Km.04, Serang, 42124, Indonesia. \\ ${ }^{2}$ Mathematics Education Department, Universitas Pendidikan Indonesia. \\ Jalan Dr. Setiabudhi No. 229, Bandung 40154, Indonesia \\ * Corresponding Author. E-mail: cecepanwar@untirta.ac.id \\ Received: 9 May 2018; Revised: 29 August 2018; Accepted: 3 November 2018
}

\begin{abstract}
This research was aimed to investigate the effect of students' self-explanation to their achievement, mental effort, and cognitive efficiency while studying mathematics, particularly in integral topics. This research used a static-group comparison design implemented to first-year undergraduate students. The subject of the study consists of 64 first year undergraduate students in one of the universities in Banten province, Indonesia. The students were divided into two classrooms, experimental and control. Experimental classroom received worked-example method whereas control classroom studying without worked-example method. Instruments used in this research include achievement tests, rating scale mental effort, deviation model of cognitive efficiency, and teaching materials in the form of worked-example. The results show that the implementation of self-explanation through worked-example helps students get a higher achievement, lower mental effort, and better cognitive efficiency compared to students who get instruction without worked-example method. The research also reveals the important role of worked-example in enhancing the ability of students' selfexplanation.
\end{abstract}

Keywords: self-explanation, mathematical cognitive efficiency, mental effort, worked-example.

How to Cite: Santosa, C., Suryadi, D., Prabawanto, S., \& Syamsuri, S. (2019). The role of worked-example in enhancing students' self-explanation and cognitive efficiency in calculus instruction. Jurnal Riset Pendidikan Matematika, 5(2), 168-180. doi:https://doi.org/10.21831/jrpm.v0i0.19602

Permalink/DOI: https://doi.org/10.21831/jrpm.v0i0.19602

\section{INTRODUCTION}

At the first year in university, mathematics or mathematics education students are faced with mathematical contents that different when they were at secondary school (Harel \& Kaput, 2002; Moore, 1994; Rach \& Heinze, 2016; Tall, 2011). Mathematics learning in university involves different ways of thinking, this conditions often appear to be a substantial hurdle in students' learning. For example, one of the courses in university is Calculus. Some students have difficulty in understanding the mathematics language, misusing of concepts, failed to justify, and less precise use of algorithms (Nursyahidah \& Albab, 2017). Harel and Kaput (2002) stated that the difficulties came from conceptual entities and their relationships with mathematical notations. Rach and Heinze (2016) saw that there are differences between mathematics learning trajectories from school to university. Further, Tall (2011) stated that the ways of mathematical thinking in undergraduate mathematics different from students' previous experience, the transformation from elementary mathematical thinking to advance mathematical thinking pinpointed at logics and rigor properties. These difficulties related to mathematical content characteristics and it is called intrinsic nature of the instructional material (Ayres \& Paas, 2012; Sweller, 2011; Sweller, Ayres, \& Kalyuga, 2011). Therefore, different ways of thinking is apparent in Calculus instruction.

Another difficulty may come from instructional design or by the manner in which the information is presented. These difficulties related to the learning method, technique, or approach that implemented by lecturers (Fukawa-Connelly, 2012; Intaros, Inprasitha, \& 
Srisawadi, 2014; Lopez, 2007; Rukavina, Zuvicbutorac, Ledic, Milotic, \& Jurdana-sepic, 2012; Santosa, 2013), and also with the textbook structure and design which is used by students to learn (McCrory \& Stylianides, 2014; Stylianides, 2014). The learning difficulties because of these conditions are called extrinsic nature of the instructional design.

Both of intrinsic and extrinsic difficulties led to the depletion of students' cognitive resource, in the other word this condition causes cognitive overload (Ayres \& Paas, 2012; Schmeck, Opfermann, Gog, Paas, \& Leutner, 2015). At this condition, students cannot find the solution from the mathematics problems that is presented. This occur because a human has a limitation when manage and process information (Baddeley, 1992, 2010, 2012; Sweller, 2011). The part of a human brain that consciously processes information that has a limitation is called working memory (Baddeley, 1992, 1996, 2000, 2003, 2012; Baddeley \& Larsen, 2007). All of the information are processed here before it is stored in long-term memory in form of schema. Because of the limitation, working memory is quite vulnerable to overload. Of course, when the cognitive overload occurs, the process of learning can be inhibited.

The difficulties related to intrinsic nature of the instructional material cannot be managed by lecturers since these deal with the difficulties of mathematics itself. Learn mathematics contents are complex learning, there are many elements that must be processed simultaneously. Also, solve mathematics problems are timeconsuming and involving many mathematical abilities (Hsu \& Silver, 2014; Khateeb, 2008; Wilhelm, 2015). Different with the intrinsic nature of material, the extrinsic nature of the instructional design is possible to be managed by a lecturer. The lecturer can reduce this type of cognitive load by implementing the suitable instructional design, rearrange, and reformulate the textbook contents and structures. To overcome these difficulties, we can set up tasks from the textbook to be implemented in the classroom. Some of the researchers argued that mathematics topics in the textbook need to get adaptation (Stylianides, 2014) since the logic of the textbook is sometimes different with the nature of mathematics discovery (Almeida, 2003; Sriraman, 2004).

One of the adaptation can be done by the lecturer is reformulating the textbook in the form of worked-example. Basically, a worked- example is a solved problem with shown step-bystep solution (NCTM, 2009). Worked-example uses as a bridge to connect students' knowledge with a novel information to solve mathematical problems. By this method, a schema can be acquired easily and rapidly (Bokosmaty, Sweller, \& Kalyuga, 2015; Pachman, Sweller, \& Kalyuga, 2014; Sweller, 2011). This is supported by Lockwood, Ellis, and Lynch (2016) studies which reveal that comprehending mathematical concepts have to involve many relevant examples to facilitate students get their understanding. By those worked-examples, students try to comprehend the problems which are presented. At this moment, they do a reflective activity to comprehend mathematical concepts and also repair misconceptions. This process is known as self-explanation.

A recent study conducted by Hodds, Alcock, and Inglis (2014), they design a booklet containing self-explanation training to students who learn mathematical proof, as a result students' proof comprehension enhanced significantly. The research study by Rau, Aleven, and Rummel (2015) also found that selfexplanation prompt combined with multiple graphic representations can significantly enhance students' learning.

Although there was much research about self-explanation strategies related to academic achievement, few of them focused on cognitive efficiency. Cognitive efficiency is related to students' achievement (performance) and effort deployed by them to accomplish a task. This effort known as mental effort (Miller, 2001; Widyanti, Johnson, \& Waard, 2010), it is the mental activity that is invested by students when they solving mathematical tasks. Learning should consider the mental effort, in order to help the students acquire knowledge efficiently. This research was conducted to explore selfexplanation related to cognitive efficiency in calculus instruction. Therefore, this research was aimed to investigate the effect of students' selfexplanation to their achievement, mental effort, and cognitive efficiency while studying mathematics, particularly in integral topics.

\section{METHOD}

\section{Design}

A static-group comparison design implemented, with post-test measurement, was employed (Fraenkel, Wallen, \& Hyun, 2012). 


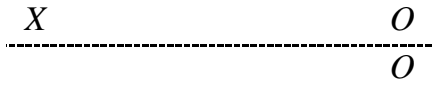

notes:

$\mathrm{X}=$ Worked-example method

$\mathrm{O}=$ Posttest

The independent variable was students' cognitive efficiency. The treatment was a worked-example method. The design shows that the students were divided into two classrooms, experimental and control. Experimental classroom received worked-example method and control classroom studying without workedexample. It is implemented to determine the effectiveness of worked-example and without worked-example method.

\section{Participants}

The participants of the study consist of first-year students studying in one of the universities in Banten, in the subject of Multivariate Calculus. The university was selected purposively. 64 students took part in this study. Each experiment and control classroom consists of 32 students.

\section{Instruments}

Instruments were used in this research were a test, rating scale mental effort, deviation model of cognitive efficiency, and workedexamples. Test instrument was used to collect data on academic achievement, a rating scale mental effort was employed to measure mental effort, and a deviation model was employed to measure cognitive efficiency, while workedexamples were used by students to learn. These instruments have been developed by the researcher.

Test Instrument. A test was an instrument to assess students' achievement in mathematical tasks. Five problems were asked to the students. The problems were the combination of several aspects; well-structured, multiple steps solution, applying concepts, proofing, word problem, mathematical expression, and geometrical illustration. Before instrument used, content validity was conducted by expert-judgement. The instrument was tested with other 23 students to determine reliability. The reliability coefficient of test instrument was 0.60 . This results met reliability requirements.
Rating Scale Mental Effort. This rating scale to measure student's mental effort when they dealt with mathematical tasks. The subjective measure of mental effort was employed. It was adapted from the scale which is constructed by Paas and Merrienboer (1993, 1994); Tuovinen and Paas (2004). Students were asked to report their invested mental effort after they accomplished every test instrument on a nine-point scale (Table 1). This instrument was translated and tested with other 25 students. The reliability (Cronbach Alpha) was 0.82, which categorized high (Santosa, Suryadi, \& Prabawanto, 2016).

Deviation Model of Cognitive Efficiency. Deviation model was used to measure mathematical cognitive efficiency. This model was constructed by Paas and Merrienboer (1993) and Tuovinen and Paas (2004). This is a suitable model to measure cognitive efficiency when comparing instructional interventions (Hoffman, 2012). It also chose regarding with its simplicity and easy to interpret. The formula of deviation model is:

$E=\frac{(z C-z U M)}{\sqrt{2}}$

where $E$ is cognitive efficiency, $C$ is achievement score and $U M$ is mental effort score. The cognitive efficiency categorized as high when the value of $\mathrm{E}$ is greater than zero (Figure 1).

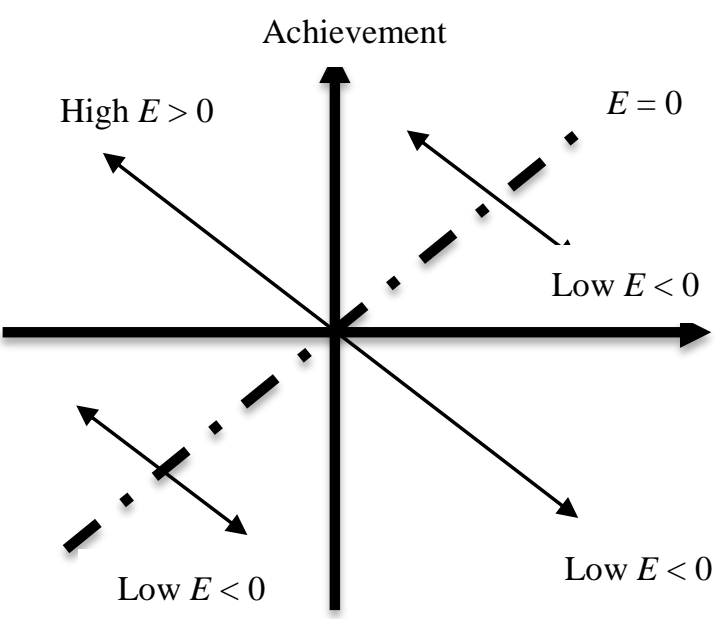

Figure 1. Visualization and categorization model of cognitive efficiency. 
Jurnal Riset Pendidikan Matematika, 5 (2), 2018 - 171

Cecep Anwar Hadi Firdos Santosa, Didi Suryadi, Sufyani Prabawanto, S. Syamsuri

Table 1. Rating Scale Mental Effort

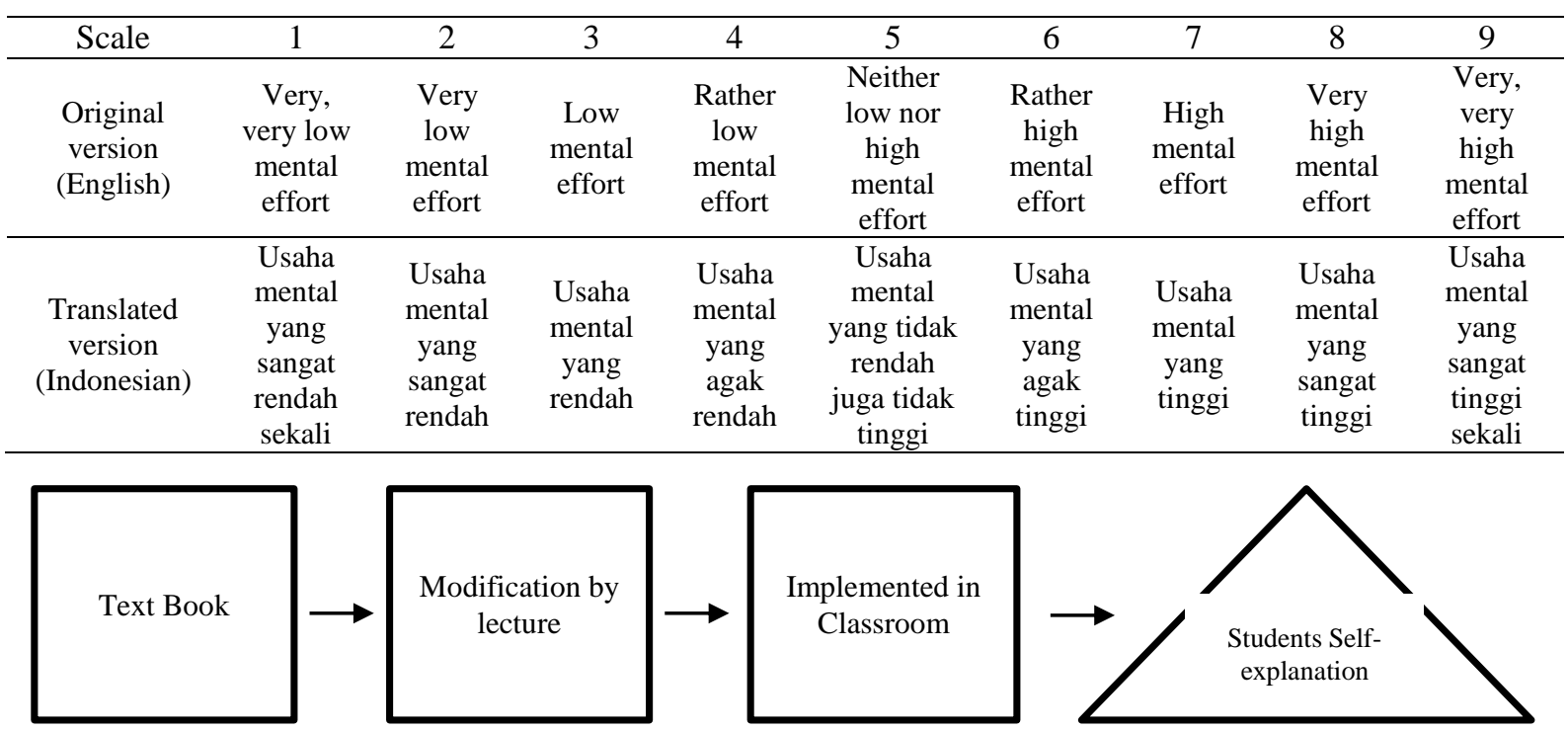

Figure 2. Modification of the Mathematical Tasks Structure (Stein et al., 1996; Stylianides, 2014)

\begin{tabular}{|c|c|}
\hline Steps & Explanation \\
\hline $\int_{0}^{1} \int_{0}^{\sqrt{1-x^{2}}}\left(4-x^{2}-y^{2}\right)^{-\frac{1}{2}} d y d x$ & Problem \\
\hline$\frac{1}{1}+\frac{1}{2} x$ & 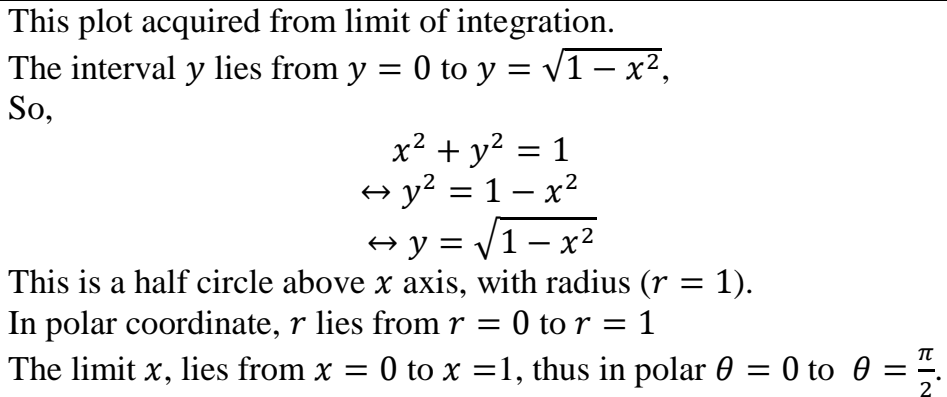 \\
\hline $\int_{0}^{\frac{\pi}{2}} \int_{0}^{1}\left(4-r^{2}\right)^{-\frac{1}{2}} r d r d \theta$ & $\begin{array}{l}\text { Changing to polar coordinate, remember that: } \\
x=r \cos \theta, y=r \sin \theta, x^{2}+y^{2}=r^{2} \text {, and } \\
d y d x \text { change to } r d r d \theta \\
\text { Pay attention with the changing of the limit of integrations. }\end{array}$ \\
\hline Steps & Explanation \\
\hline $\int_{0}^{2 \pi} \int_{0}^{\infty} e^{-r^{2}} r d r d \theta$ & Problem \\
\hline$\leftrightarrow \lim _{a \rightarrow \infty} \int_{0}^{2 \pi} \int_{0}^{a} e^{-r^{2}} r d r d \theta$ & $\begin{array}{l}\text { This is the method to solve the improper integral (infinite limits) } \\
\text { This topic is presented in indeterminate forms and improper } \\
\text { integrals topic }\end{array}$ \\
\hline $\begin{array}{l}\leftrightarrow \lim _{a \rightarrow \infty} \int_{0}^{2 \pi}\left[-\frac{1}{2} e^{-r^{2}}\right]_{0}^{a} d \theta \\
\leftrightarrow \lim _{a \rightarrow \infty} \frac{1}{2} \int_{0}^{2 \pi}\left(1-e^{-a^{2}}\right) d \theta\end{array}$ & Solve the integral form \\
\hline$\leftrightarrow \frac{1}{2} \lim _{a \rightarrow \infty}\left(\theta-\theta e^{-a^{2}}\right)_{0}^{2 \pi}=\frac{1}{2} 2 \pi=\pi$ & Solve using your knowledge about limit. \\
\hline
\end{tabular}

Figure 3.Worked-example to guide students solve the problems. 
Worked-example Instrument. This instrument was developed to give student guidance when they learn mathematics topics. The method to develop this instrument refer to Stein, Grover, and Henningsen (1996) and Stylianides (2014) works with some modification. Tasks from the textbook were reinterpreted, restructured, and rewrote by considering worked-example principles (Figure 2). Figure 3 show one of the illustrations of worked-example performed to students in the classroom when they learn the topic of double integral.

\section{FINDINGS AND DISCUSSION}

\section{Students' Achievement}

Table 2 show that descriptively, the mean score of students' achievement in the classroom with worked-example is 52.70 , which is higher than without worked-example, 33.70. Also, according to statistical test (t-test), there is a significant different between classroom with worked-example and without $(t=-.258, p<$ .001) (Table 3). This result indicated that learning with worked-example can enhance students' achievement in mathematics.

Table 2. Description of Achievement between Worked-example (WE) and without Workedexample (WWE)

\begin{tabular}{lcc}
\hline \multirow{2}{*}{ Statistics } & \multicolumn{2}{c}{ Achievement } \\
\cline { 2 - 3 } & WWE & WE \\
\hline Mean & 33.70 & 52.70 \\
Median & 21.67 & 52.00 \\
Standard Deviation & 30.41 & 17.95 \\
\hline
\end{tabular}

Table 3. Achievement Comparison between Worked-example (WE) and Without Workedexample (WWE)

\begin{tabular}{lrr}
\hline \multicolumn{1}{c}{ Statistics } & WWE & \multicolumn{1}{c}{ WE } \\
\hline Mean & 33.70 & 52.70 \\
Variance & 924.48 & 322.04 \\
$\mathrm{t}$ Stat & $-2.58^{*}$ & \\
$\mathrm{t}$ Critical one-tail & 1.69 & \\
$* \alpha=0.01$ & &
\end{tabular}

\section{Students' Mental Effort}

Lower score of mental effort indicates that students can manage their cognitive resource efficiently. The result confirms that mental effort scores for students who learn mathematics with worked-example are lower than without workedexample (Table 4). The median mental effort for students who get worked-example is 5, which is categorized as "neither low nor high mental effort", and for students without worked-example are 7, "high mental effort" (Table 4). Also, Table 4 show that the maximum students' mental effort score with worked-example is 6 (rather high mental effort) lower than without workedexample, 8 (very high mental effort).

The data type of mental effort in this research categorized as ordinal data. According to Norman (2010) and Kline (2011), ordinal data types can be treated as interval data, if they meet several requirements. First, the scale of the response is more than five, second, the sample size is sufficiency large, and third, the data distribution is normal. For the testing of normality can be replaced with regard skewness and kurtosis, skewness must be between -3 and 3, while the kurtosis must be between -10 and 10 .

Table 4. Description of Mental Effort between Worked-example and Without Worked-example

\begin{tabular}{lrr}
\hline \multirow{2}{*}{ Statistics } & \multicolumn{2}{c}{ Mental Effort } \\
\cline { 2 - 3 } & WWE & WE \\
\hline Mean & 6.43 & 4.57 \\
Median & 7.00 & 5.00 \\
Standard Deviation & 1.14 & 0.90 \\
Kurtosis & -0.71 & -0.51 \\
Skewness & -0.35 & -0.21 \\
Minimum & 4.00 & 3.00 \\
Maximum & 8.00 & 6.00 \\
\hline
\end{tabular}

The data in this study met the criteria proposed by Norman (2010) and Kline (2011) above. First, the scale of the response is nine (Table 1). Second, the number of samples is 64 (more than 30). Third, the skewness for the data WE and WWE are -0.21 and -0.35 , while the kurtosis respectively -0.51 and -0.71 (Table 4). So the data can be considered as interval data and analyzed by parametric tests.

Table 5. Mental Effort Comparison between Worked-example and Without Worked-example

\begin{tabular}{lrr}
\hline \multicolumn{1}{c}{ Statistics } & \multicolumn{1}{c}{ WWE } & WE \\
\hline Mean & 6.43 & 4.56 \\
Variance & 1.29 & 0.80 \\
$t$ Stat & 6.20 & \\
$P(T \leq t)$ one-tail & $1.027 \mathrm{E}-07^{*}$ & \\
$t$ Critical one-tail & 1.68195236 & \\
$P(T \leq t)$ two-tail & $2.0541 \mathrm{E}-07^{*}$ & \\
$t$ Critical two-tail & 2.02 & \\
$* \alpha=0.05$ & &
\end{tabular}

Statistical test (t-test) for mental effort shows that there is a significant different between students who get worked-example and without $(t=6.20, p<.001)$ (Table 5). This result indicated that worked-example method has an effect on students' mental effort. Students with worked- 
example have lower mental effort mean score than without worked-example (Table 5). This result indicated that worked-example can reduce students' mental (cognitive) load.

\section{Students' Mathematical Cognitive Efficiency}

Lower mental effort score is not sufficient condition to determine the cognitive efficiency. The students' mental effort score have to evaluate simultaneously with the students' achievement to determine the students' cognitive efficiency.

Figure 4 show the score of cognitive efficiency for the students who get worked-example is 0.73 , which is categorized as high cognitive efficiency. It also indicates that student can manage their cognitive efficiently by studying examples and do self-explanation. This condition is different with students who learn mathematics without worked-example, the score of cognitive efficiency is -0.73 , which is categorized as low cognitive efficiency, indicated that student cannot manage their cognitive efficiently.

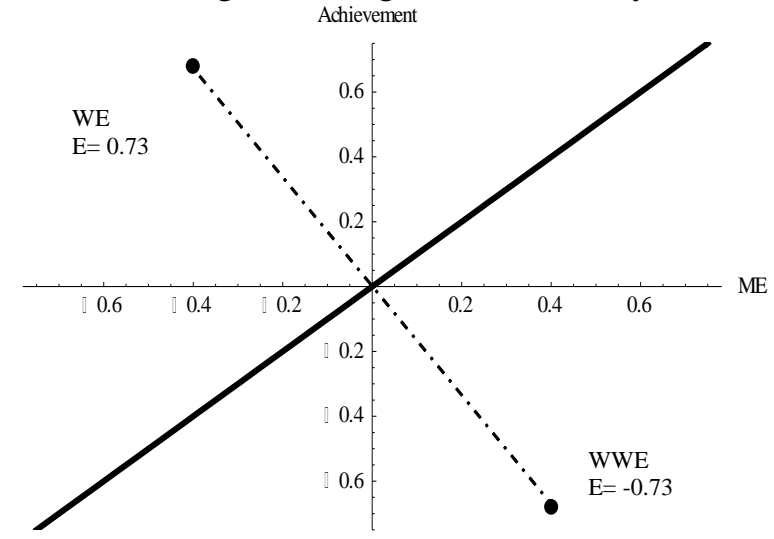

Figure 4. Cognitive Efficiency between Worked-example (WE) and Without (WWE)

\section{Self-Explanation through Worked-example}

In this section, are shown the work of students who learn using worked-example and without worked-example when asked following problem:

Prove that:

$\int_{0}^{\infty} \int_{0}^{\infty} \frac{1}{\left(1+x^{2}+y^{2}\right)^{2}} d y d x=\frac{\pi}{4}$

To answer the problem above, students have to comprehend about double integral, they also must grasp several other mathematics topics; techniques of integration, indeterminate forms and improper integrals, and also there are polar coordinates.
Figure 5, Figure 6, Figure 7, and Figure 8 show the answer of students to represent a class of experimental (Student ST-1 and ST-2) and control (Student ST-3 and ST-4).

The answer to the problem as stated in Figure 5, shows that the student ST-1 was able to solve the problem. ST-1 understood what to do in making correct answer. Starting from changing the Cartesian coordinates to polar coordinates, understanding the changing of lower and upper limits of the integral, understand the technique of integration, understanding the completion of the indefinite and improper integral form, and it calculations. According to Syamsuri and Santosa (2017) students of ST-1 is classified in holistic global type. ST-1 solved the mathematical problem using three knowledge of mathematics, i.e.: application, meanings and logical relationship.

Meanwhile, Figure 6 show that students ST-2 still has not been able to prove completely the problem. However, ST-2 has shown the correct steps in answering questions. Starting from changing to polar coordinates, understanding the changing of lower and upper limits of the integral, and understand the form of the indefinite and improper integral. According to Syamsuri and Santosa (2017) students of ST-2 is classified in partial global type. ST-2 solved the mathematical problem using less meanings on mathematical concepts. In addition, an analysis using APOS Theory, ST-2 didn't perform interiorization "Action' into "Process". Mental mechanism arises when constructing proof only interiorization and coordination, while encapsulation does not appear (Syamsuri, Purwanto, Subanji, \& Irawati, 2017).

Figure 7 shows the student ST-3 answer has not been able to prove the problem. ST-3 has not shown the correct steps in answering the question. No attempt was made to change from polar to Cartesian coordinates, does not understand the integral boundary change, not being able to apply the techniques of integration, and does not understand the completion involving the indefinite and improper integral form. According to Syamsuri and Santosa (2017) students of ST-3 is classified in partial local type. ST-3 unsolved the mathematical problem well. In addition, an analysis using APOS Theory, ST-3 have done imperfection "Action', so he didn't perform interiorization "Action' into "Process (Syamsuri et al., 2017). 
Jurnal Riset Pendidikan Matematika, 5 (2), 2018 - 174

Cecep Anwar Hadi Firdos Santosa, Didi Suryadi, Sufyani Prabawanto, S. Syamsuri

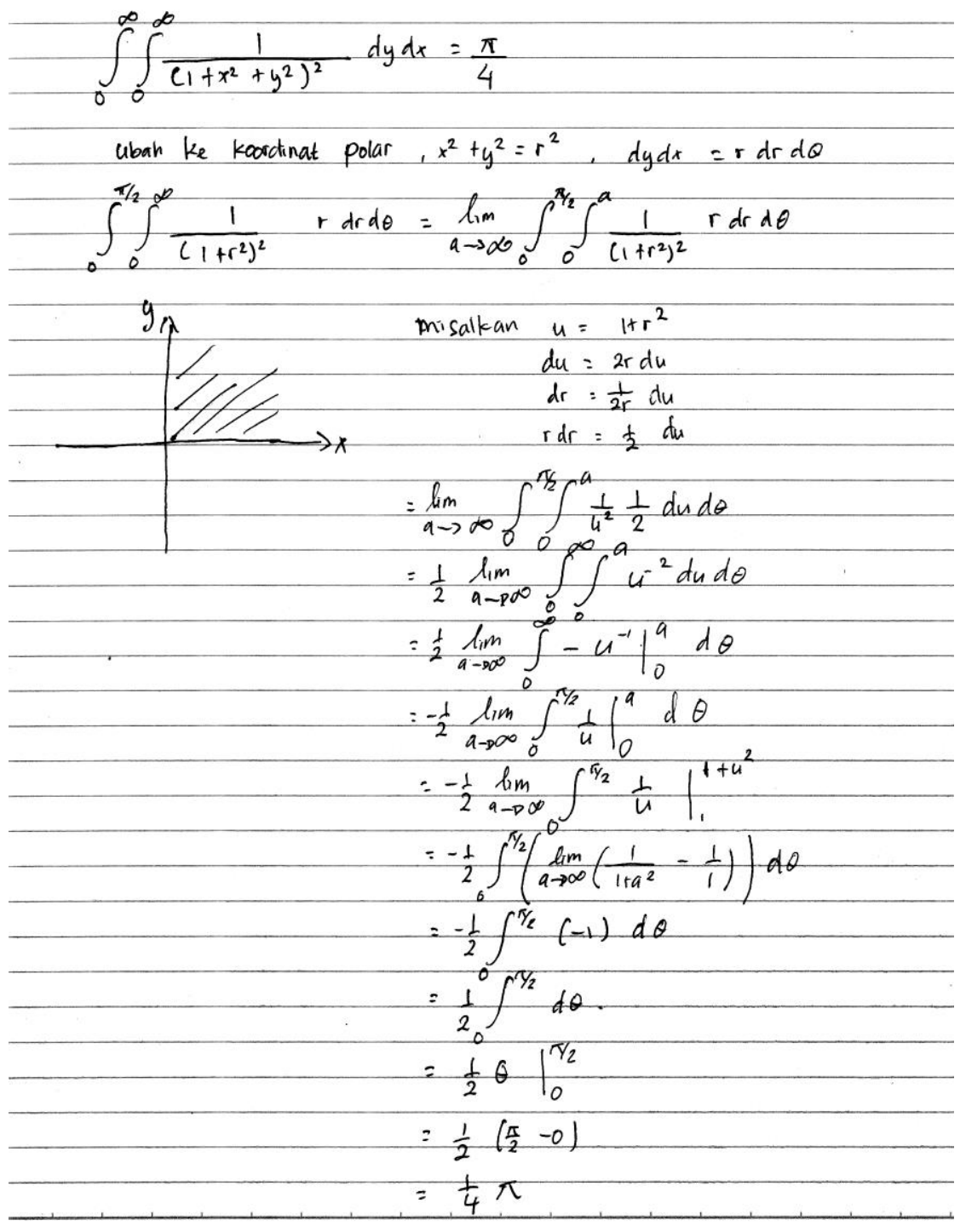

Figure 5. The answer of Student ST-1 in the Classroom Implemented Worked-example Method.

The description in Figure 8 is relatively the same as that in Figure 7 where student ST-4 has not been able to prove the problem. ST-4 has not been able to demonstrate the correct steps to get the right answer.

Further, students ST-1 and ST-2 have the awareness what to plan and what to do to solve the problem. While the students ST-3 and ST-4 does not have the awareness in solving a given problem. According to Inam (2016) students of ST-1 and ST-2 have a metacognitive ability, especially in the aspect of awareness, while students of ST-3 and ST-4 do not have that ability.

\section{Discussion}

Research findings show that learning with worked-example can enhance students' achievement in the multivariable calculus instruction.
Students' achievement relies on the knowledge that has been formed in their cognitive. In multivariable calculus instruction, students must understand several prerequisite contents, there are, function, algebra, analytical geometry, and trigonometry (Cohen, 1995; White \& Mitcelmore, 1996). Furthermore, students must also understand concepts in differential and integral for one variable function.

Those prerequisite concepts must already exist in their long term memory in the form of knowledge schemes before they learn multivariable calculus. However, there are many students who have not mastered these concepts. This situation led to non optimal learning condition. This occurs when students face difficulty when processing information in their working memory. As a result, students go through cognitive overload circumstance. 
Jurnal Riset Pendidikan Matematika, 5 (2), 2018 - 175

Cecep Anwar Hadi Firdos Santosa, Didi Suryadi, Sufyani Prabawanto, S. Syamsuri

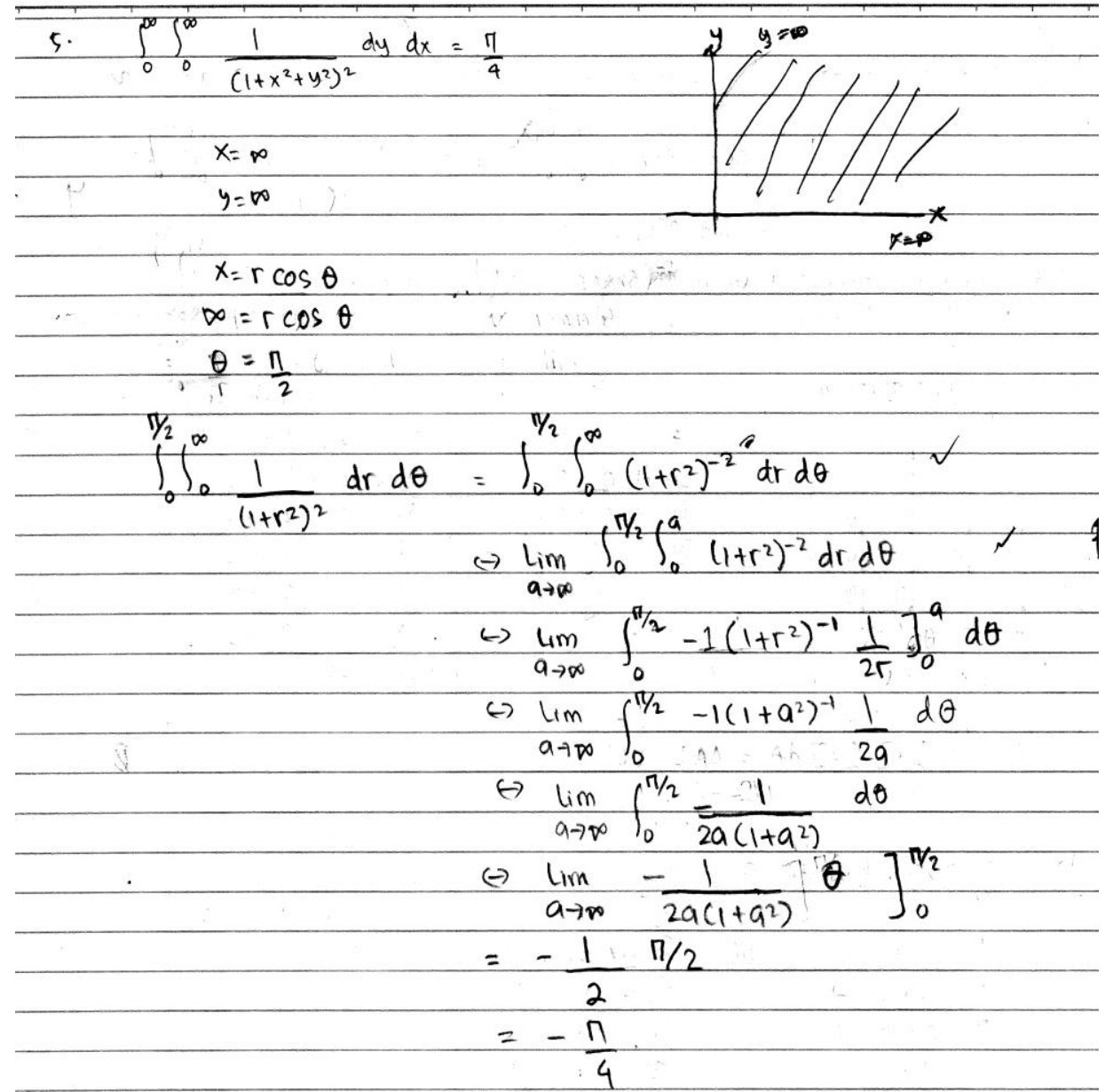

Figure 6. The answer of Student ST-2 in the Classroom Implemented Worked-example Method.

\begin{tabular}{l} 
5. $\int_{0}^{\infty} \frac{1}{\left(1+x^{2}+y^{2}\right)} d y d x=\frac{\pi}{4}$ \\
\hline $\lim _{a \rightarrow \infty} \int_{0}^{\infty} \int_{0}^{\infty} \frac{1}{\left(1+x^{2}+y^{2}\right)} d y d x=$ \\
$\left.\leftrightarrow \lim _{a \rightarrow \infty} \int_{0}^{\infty} \frac{1}{\left(1+x^{2}+\frac{1}{3} y^{3}\right)}\right]_{0}^{\infty} d x$ \\
$\left.\qquad \lim _{a \rightarrow \infty} \int_{0}^{\infty} \sqrt{1+x^{2}+\frac{1}{3} y^{3}}\right]_{0}^{\infty} d x$. \\
$\leftrightarrow \lim _{a \rightarrow \infty}$
\end{tabular}

Figure 7. The answer of Student ST-3 in the Classroom without Implemented Worked-example 
Jurnal Riset Pendidikan Matematika, 5 (2), 2018 - 176

Cecep Anwar Hadi Firdos Santosa, Didi Suryadi, Sufyani Prabawanto, S. Syamsuri

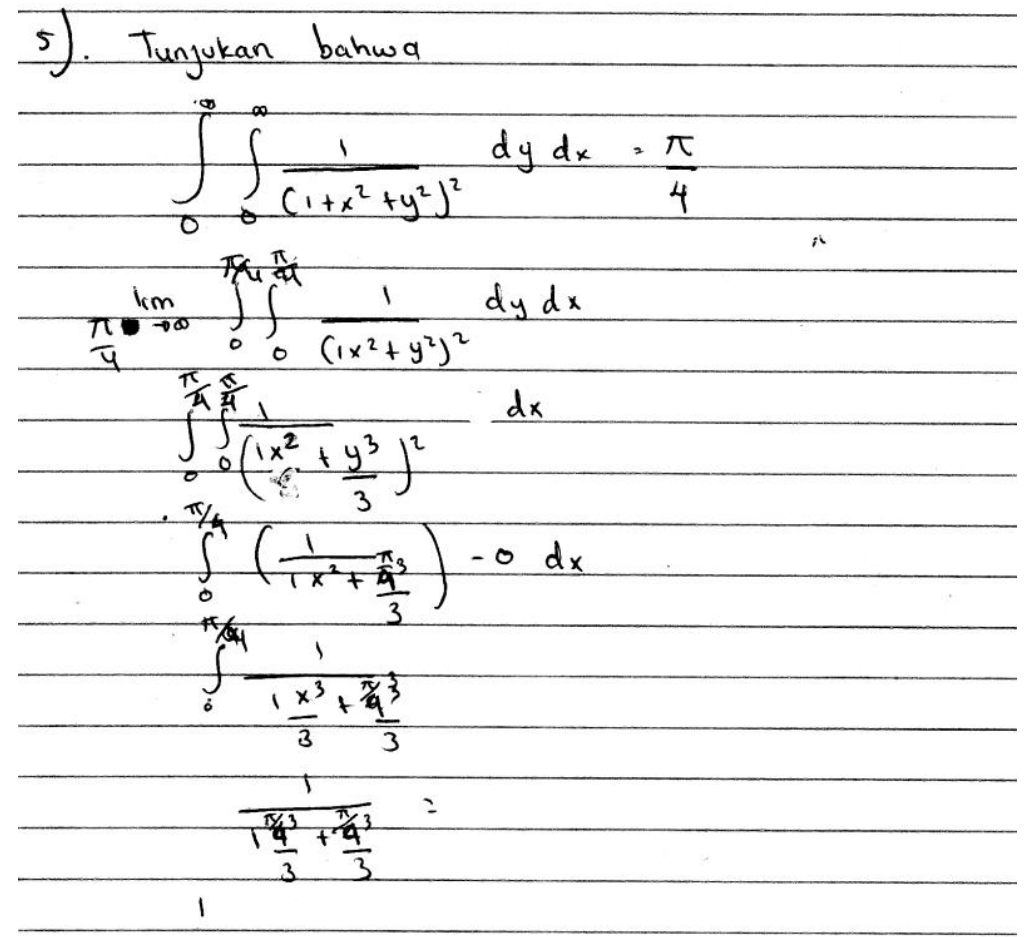

Figure 8. The answer of Student ST-4 in the Classroom without Implemented Worked-example.

There are several cognitive load source (Kalyuga, 2011), first, an intrinsic cognitive load which related to the content difficulties in multivariable calculus instruction. Second, an extraneous cognitive load which related to the manner how the calculus contents were performed. Third, germane load which related to students' mental effort to form knowledge shemes.

In this research, the implementation of the worked-example method was an effort to reduce extraneous cognitive load. The use of workedexample will accelerate the formation of knowledge schemes in students' long-term memory. Also, by learning worked-examples, students will complete the essential knowledge to their longterm memory and will be useful when they face mathematical problems in multivariable calculus instruction. This is the reason why the workedexample method has a positive influence on learning achievement.

In addition to performance, the research also reveals that worked-example reduces students' mental effort. Through the workedexample method, students' knowledge schemes were developed base on the "borrowing" principle (Sweller, 2008). By way of "borrowing" other knowledge schemes from an expert (in form of worked-example), the formation of students' knowledge schemes is easier. This automatically reduces students' cognitive load.
The high of students achievement and low students' mental effort who implement workedexample compared to students' who do not implement worked-example method indicate that worked-example led to the students' cognitive efficiency. This condition was shown by students' cognitive efficiency score. Students who implement worked-example method have a positive average score, however, students' who do not implement worked-example have a negative average score.

In essence, students who implement worked-example method are able to manage their cognitive resources to form knowledge schemes. In other words, the mental effort that students deploy is relevant to the formation of knowledge schemes. When knowledge schemes have been formed, students will succeed in solving mathematical problems on the topic of multivariable calculus.

When students learn mathematics through worked-example, they do a reflective activity to comprehend mathematics concepts. This reflective activity is known as self-explanation. This explanation process in students' cognition is very important in a learning activity (Durkin, 2011; Hodds et al., 2014; Kyungbin, Kumalasari, \& Howland, 2011; Rau et al., 2015). Selfexplanation is useful to foster the integration of prior knowledge and new knowledge to form more complete schema about mathematics topics. 
Students who learn mathematics through worked-example method also have the awareness to control their cognitive to solve mathematics problems. This awareness ability is not owned by students who studying without worked-example method.

Thus, the worked-example method is efficiently able to form a knowledge scheme. This is in accordance with the information processing theory which states that successful learning is learning that is able to store information being process in working memory into long-term memory. Learning that is not able to store information to students' long-term memory is inefficient learning.

\section{CONCLUSIONS}

Based on data analysis, findings, and discussion, we can conclude that the implementation of worked-example on mathematics instruction has important role in students' academic achievement, mental effort, and cognitive efficiency. Learning by examples in form of workedexample can boost students' schema acquisition rapidly. Worked-example also can repair students' misconceptions about mathematics topics.

Therefore, it can be stated that learning by worked-example is very useful in learning mathematics. With these findings, the use workedexample can be considered to be implemented in the mathematics classroom to improve students' achievement and reduce students' mental workload.

More broadly, research is also needed to confirm these findings, how self-explanation with examples can perform better in learning mathematics compare with instruction without it by considering other factors, such as gender, learning style, motivation, or students' prior knowledge. It is also necessary to investigate the role of self-explanation when students deal with the tasks in complex mathematical problem solving.

\section{REFERENCES}

Almeida, D. (2003). Engendering proof attitudes : can the genesis of mathematical knowledge teach us anything? International Journal of Mathematical Education in Science and Technology, 34(4), 479-488. doi:http://doi.org/10.1080/002073903100 0108574

Ayres, P., \& Paas, F. (2012). Cognitive load theory: new directions and challenges. Applied Cognitive Psychology, 26(6), 827-832. doi:http://doi.org/10.1002/acp.2882

Baddeley, A. (1992). Working memory. Science, 255 , 556-559. doi:http://doi.org/10.1126/science.173635 9

Baddeley, A. (1996). Exploring the central executive. The Quarterly Journal of Experimental Psychology, 49(1), 5-28.

Baddeley, A. (2000). The episodic buffer: A new component of working memory? Trends in Cognitive Sciences, 4(11), 417-423. http://doi.org/10.1016/S13646613(00)01538-2

Baddeley, A. (2003). Working memory: Looking back and looking forward. Nature Reviews: Neuroscience, 4(10), 829-39. doi:http://doi.org/10.1038/nrn1201

Baddeley, A. (2010). Working memory. Current Biology, 20(4), 136-140. http://doi.org/10.1016/j.cub.2009.12.014

Baddeley, A. (2012). Working memory: Theories, models, and controversies. Annual Review of Psychology, 63, 1-29. doi:http://doi.org/10.1146/annurev-psych120710-100422

Baddeley, A. D., \& Larsen, J. D. (2007). The phonological loop: Some answers and some questions. The Quarterly Journal of Experimental Psychology, 60(4), 512-518. doi:http://doi.org/10.1080/174702106011 47663

Bokosmaty, S., Sweller, J., \& Kalyuga, S. (2015). Learning geometry problem solving by studying worked examples: effects of learner guidance and expertise. American Educational Research Journal, 52(2), 307-333.

doi:http://doi.org/10.3102/000283121454 9450

Cohen, D. (1995). Crossroads in mathematics: Standards for introductory college mathematics before calculus. Memphis, TN: AMATYC, State Technical Institute at Memphis.

Durkin, K. (2011). The self-explanation effect when learning mathematics: A metaanalysis. In Conference on Building and Educatioan Science: Investigating Mechanisms (pp. 1-5). Washington, DC: 
Society for Research on Educational Effectivenss Spring 2011.

Fraenkel, J. R., Wallen, N. E., \& Hyun, H. H. (2012). How to design and evaluate research in education (8th ed.). New York, NY: McGraw-Hill.

Fukawa-Connelly, T. (2012). Classroom sociomathematical norms for proof presentation in undergraduate in abstract algebra. The Journal of Mathematical Behavior, 31(3), 401-416. doi:http://doi.org/10.1016/j.jmathb.2012.0 4.002

Harel, G., \& Kaput, J. (2002). The role of conceptual entities and their symbols in building advance mathematical concepts. In D. Tall (Ed.), Advanced mathematical thinking (pp. 83-94). New York, NY: Kluwer Academic Publisher.

Hodds, M., Alcock, L., \& Inglis, M. (2014). Selfexplanation training improves proof comprehension. Journal for Research in Mathematics Education, 45(1), 62-101. doi:http://doi.org/10.5951/jresematheduc. 45.1.0062

Hoffman, B. (2012). Cognitive efficiency: A conceptual and methodological comparison. Learning and Instruction, 22(2), 133-144. doi:http://doi.org/10.1016/j.learninstruc.2 011.09.001

Hsu, H.-Y., \& Silver, E. A. (2014). Cognitive complexity of mathematics instructional tasks in a Taiwanese classroom: An examination of task sources. Journal for Research in Mathematics Education, 45(4), 460-496. doi:http://doi.org/10.5951/jresematheduc. 45.4.0460

Inam, A. (2016). Euclidean geometry's problem solving based on metacognitive in aspect of awareness. International Electronic Journal of Mathematics Education, 11(7), 2319-2331.

Intaros, P., Inprasitha, M., \& Srisawadi, N. (2014). Students' problem solving strategies in problem solving-mathematics classroom. Procedia - Social and Behavioral Sciences, 116, 4119-4123. doi:http://doi.org/10.1016/j.sbspro.2014.0 1.901

Kalyuga, S. (2011). Cognitive load theory: How many types of load does it really need?
Educational Psychology Review, 23(1), 119. doi:http://doi.org/10.1007/s10648010-9150-7

Khateeb, M. (2008). Cognitive load theory and mathematics education (Unpub;ished master's theses). University of New South Wales, New South Wales.

Kline, R. B. (2011). Principles and practice of structural equation modelling (3rd ed.). New York, NY: Guilford Press.

Kyungbin, K., Kumalasari, C. D., \& Howland, J. L. (2011). Self-explanation prompts on problem-solving performance in an interactive learning environment. Journal of Interactive Online Learning, 10(2), 96112.

Lockwood, E., Ellis, A. B., \& Lynch, A. G. (2016). Mathematicians' example-related activity when exploring and proving conjectures. International Journal of Research in Undergraduate Mathematics Education, 2(2), 165-196. doi:http://doi.org/10.1007/s40753-0160025-2

Lopez, O. S. (2007). Classroom diversification: a strategic view of educational productivity. Review of Educational Research, 77(1), 28-80.

McCrory, R., \& Stylianides, A. J. (2014). Reasoning and proving in mathematics textbooks for prospective elementary teachers. International Journal of Educational Research, 64, 119-131. doi:http://doi.org/10.1016/j.ijer.2013.09.0 03

Miller, S. (2001). Workload measures. Iowa City, IA: National Advanced Driving Simulator.

Moore, R. C. (1994). Making the transition to formal proof. Educational Studies in Mathematics, 27, 249-266. doi:http://doi.org/10.1007/BF01273731

NCTM. (2009). Focus in high school mathematics: reasoning and sense making. Reston, VA: Author. doi: http://doi.org/10.5951/mathteacher.106.8. 0635

Norman, G. (2010). Likert scales, levels of measurement and the "laws." Advance in Health Science Education, 15, 625-632. Retrieved from http://www.fammed.ouhsc.edu/research/F MSRE\%25 
Nursyahidah, F., \& Albab, I. U. (2017). Investigating student difficulties on integral calculus based on critical thinking aspects. Jurnal Riset Pendidikan Matematika, 4(2), 211-218. doi:http://doi.org/http://dx.doi.org/10.218 31/jrpm.v4i2.15507

Paas, F. G. W. C., \& Merrienboer, J. J. G. van. (1994). Instructional control of cognitive load in the training of complex cognitive tasks. Educational Psychology Review, 6(4), 351-371.

Paas, F. G. W. C., \& Merrienboer, J. J. G. van. (1993). The efficiency of instructional conditions: an approach to combine mental effort and performance measures. Human Factors, 35(4), 737-743.

Pachman, M., Sweller, J., \& Kalyuga, S. (2014). Effectiveness of combining worked examples and deliberate practice for high school geometry. Applied Cognitive Psychology, 28, 685-692. doi:http://doi.org/10.1002/acp.3054

Rach, S., \& Heinze, A. (2016). The transition from school to university in mathematics: which influence do school-related variables have? International Journal of Science and Mathematics Education, 121. doi:http://doi.org/10.1007/s10763016-9744-8

Rau, M. A., Aleven, V., \& Rummel, N. (2015). Successful learning with multiple graphical representations and selfexplanation prompts. Journal of Educational Psychology, 107(1), 30-46. doi:http://doi.org/10.1037/a0037211

Rukavina, S., Zuvic-butorac, M., Ledic, J., Milotic, B., \& Jurdana-sepic, R. (2012). Developing positive attitude towards science and mathematics through motivational classroom experiences. Science Education International, 23(1), 619.

Santosa, C. A. H. F. (2013). Mengatasi kesulitan mahasiswa ketika melakukan pembuktian matematis formal. Jurnal Pengajaran MIPA, 18(2), 152-160. Retrieved from http://journal.fpmipa.upi.edu/index.php/jp mipa/article/viewFile/3/3

Santosa, C. A. H. F., Suryadi, D., \& Prabawanto, S. (2016). Pengukuran efisiensi kognitif matematis di perguruan tinggi. In Seminar Nasional Matematika dan Pendidikan
Matematika. Cirebon: Fakultas Keguruan dan Ilmu Pendidikan, Universitas Swadaya Gunung Jati.

Schmeck, A., Opfermann, M., Gog, T. van, Paas, F., \& Leutner, D. (2015). Measuring cognitive load with subjective rating scales during problem solving: Differences between immediate and delayed ratings. Instructional Science, 43(1), 93-114. doi:http://doi.org/10.1007/s11251-0149328-3

Sriraman, B. (2004). The characteristics of mathematical creativity. Mathematics Educator, 14(1), 19-34.

Stein, M. K., Grover, B. W., \& Henningsen, M. (1996). Building student capacity for mathematical thinking and reasoning: An analysis of mathematical tasks used in reform classrooms. American Educational Research Journal, 33(2), 455-488. doi:http://doi.org/10.3102/000283120330 02455

Stylianides, G. J. (2014). Textbook analyses on reasoning and proving: significance and methodological challenges. International Journal of Educational Research, 64, 6370.

doi:http://doi.org/10.1016/j.ijer.2014.01.0 02

Sweller, J. (2008). Human Cognitive Architecture. In J. M. Spector, M. D. Merril, J. J. G. van Merriënboer, \& M. P. Driscoll (Eds.), Handbook of research on educational communications and technology (pp. 369-381). New York, NY: Lawrence Erlbaum Associates.

Sweller, J. (2011). Cognitive load theory. In J. P. Mestre \& B. H. Ross (Eds.), The psychology of learning and cognition in education (pp. 37-74). Oxford, UK: Academic Press.

Sweller, J., Ayres, P., \& Kalyuga, S. (2011). Cognitive load theory: explorations in the learning sciences, instructional systems and performance technologies. London, UK: Springer.

Syamsuri, Purwanto, Subanji, \& Irawati, S. (2017). Using APOS theory framework: Why did students unable to construct a formal proof? International Journal on Emerging Mathematics Education, 1(2), 135-146. doi:http://doi.org/http://dx.doi.org/10.129 
Jurnal Riset Pendidikan Matematika, 5 (2), 2018 - 180

Cecep Anwar Hadi Firdos Santosa, Didi Suryadi, Sufyani Prabawanto, S. Syamsuri

28/ijeme.v1i2.5659

Syamsuri, \& Santosa, C. A. H. F. (2017). Karakteristik pemahaman mahasiswa dalam mengonstruksi bukti matematis. Jurnal Review Pembelajaran Matematika, 2(2). 131-143.

Tall, D. (2011). Perceptions, operations and proof in undergraduate mathematics. The De Morgan Journal, 1(1), 19-27.

Tuovinen, J. E., \& Paas, F. (2004). Exploring multidimensional approaches to the efficiency of instructional conditions. Instructional Science, 32, 133-152. doi:http://doi.org/10.1023/B:TRUC.00000 21813.24669.62
White, P., \& Mitcelmore, M. (1996). Conceptual knowledge in introductory calculus. Journal for Research in Mathematics Education, 79-95.

Widyanti, A., Johnson, A., \& Waard, D. De. (2010). Pengukuran beban kerja mental dalam searching task dengan metode rating scale mental effort (RSME). J@ti Undip: Jurnal Teknik Industri, V(1), 1-6.

Wilhelm, A. G. (2015). Mathematics teachers' enactment of cognitively demanding tasks: investigating links to teachers' knowledge and conceptions. Journal for Research in Mathematics Education, 45(5), 636-674. 